\title{
Одномодовый Er-Yb волоконный усилитель с большим диаметром поля моды
}

\author{
М.М. Худяков ${ }^{1,2, *}$, С.С. Алёшкина ${ }^{1}$, Т.А. Кочергина ${ }^{1}$, К.К. Бобков ${ }^{1}$, А.С. Лобанов $^{3}$, \\ Д.С. Липатов ${ }^{3}$, А.Н. Абрамов ${ }^{3}$, А.Н. Гурьянов ${ }^{3}$, М.М. Бубнов ${ }^{1}$, М.Е. Лихачёв ${ }^{1}$ \\ ${ }^{1}$ Научный иентр волоконной оптики РАН \\ ${ }^{2}$ Московский физико-технический институт (государственный университет) \\ ${ }^{3}$ Институт химии высокочистых веществ им. Г.Г. Девятых РАН \\ *E-mail: DAngeL.74@gmail.com
}

DOI:10.31868/RFL2018.65-66

Эрбий-иттербиевые волоконные световоды являются одним из ключевых элементов в современных линях связи и лазерных системах, где требуется достижение средней мощности на уровне от сотен мВт до единиц Вт. Сердцевина в таких световодах изготавливается на основе кварцевого стекла, легированного высокими концентрациями оксида фосфора (10-15 мол.\%), что обусловлено высокой эффективностью передачи возбуждения от атомов иттербия к атомам эрбия в такой стеклянной матрице. В то же время высокий уровень легирования оксидом фосфора приводит в росту числовой апертуры сердцевины до уровня $\sim 0.2$. Условие одномодовости световода на рабочей длине волны $1550 \mathrm{Hм}$ требует в этом случае изготовления сердцевины с относительно малым диаметров, порядка 5-7 мкм. Так как эрбий-иттербиевые лазеры и усилители накачиваются по оболочке, малое соотношение диаметра сердцевины к диметру оболочки приводит к снижению скорости поглощения накачки и увеличению эффективной длины активного световода. Малый диаметр сердцевины и большая длина активного световода являются причинами низкого порога нелинейных эффектов. Как следствие стандартные конструкции эрбий-иттербиевых световодов практически не используются при усилении сигнала в импульсных лазерах. Наиболее успешная попытка увеличения пиковой мощностью эрбийиттербиевыех усилителей является работа [1], в которой был использован активный световод из фосфатного стекла с сердцевиной диметром 25 мкм легированной 15 вес.\% иттербия и 3 вес.\% эрбия и была продемонстрирована пиковая мощность 128 кВт с дифференциальной эффективностью 1,6\%. Однако, использование фосфатных световодов связано большими трудностями, связанными с их изготовлением и несовместимостью с волоконными схемами на основе кварцевого стекла. Таким образом, для использования эрбий-иттербиевых световодов при усилении излучения с высокой пиковой мощностью перспективнее выглядит подход оптимизации стеклянной матрицы сердцевины, а именно уменьшение разности показателей преломления между сердцевиной и оболочкой при одновременном сохранении высокой концентрации оксида фосфора в сердцевине. Одной из реализаций данного подхода является создание "пьедестала" с повышенным показателем преломления вокруг сильно легированной сердцевины для сохранения малой числовой апертуры. В данном случае в зависимости от конструкции усилителя была продемонстрирована дифференциальная эффективность от 5\% до 46\% [2,3]. Проблемой данного метода является трудность реализации самого световода (и как следствие его высокая стоимость), а так же сложности реализации одномодового режима работы в силу дополнительной волноволной структуры - в большинстве работ авторы использовали ввод сигнала при помощи объемной оптики для согласования выборочного возбуждения основной моды. В настоящей работе 
предлагается совместное легирование сердцевины оксидом фосфора и фтором, для сохранения низкой числовой апертуры и высокой эффективности передачи возбуждения от атомов иттербия атомам эрбия.
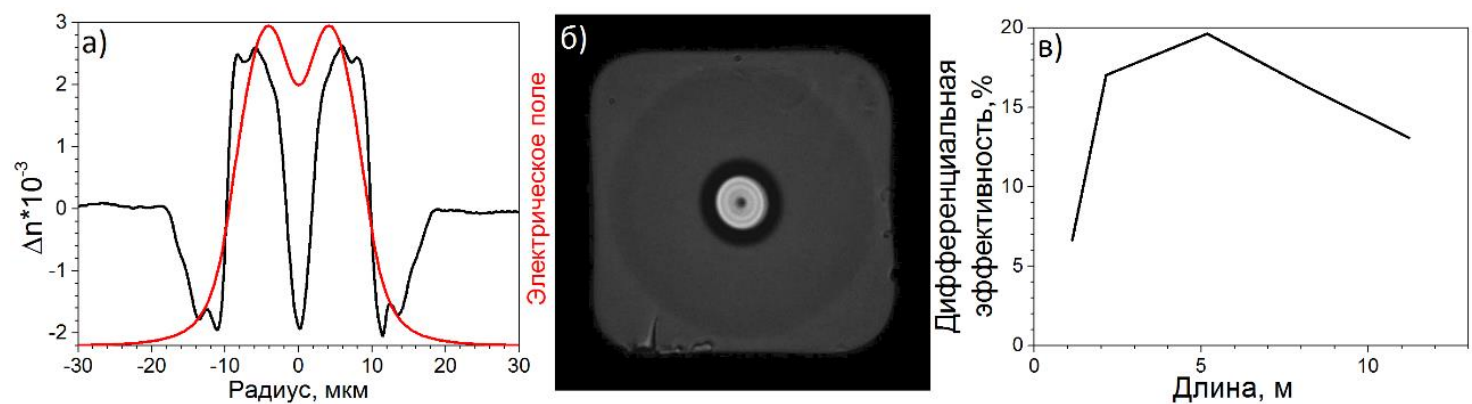

Рис.1. а) Профиль показателя преломления световода и распределения поля фундаментальной моды; б) Фотография торца световода; в) Зависимость дифференциальной эффективности от длины световода.

Заготовка для световода представленного в данной работе была изготовлена MCVD методом. Сердцевина была легирована 5 мол.\% оксида фосфора, 0,5 вес.\% фтора, 0,9 вес.\% иттербия и 0,001 вес.\% эрбия. Заготовка была сполирована до формы квадрата и вытянута с внешними размерами 119х119 мкм. Профиль показателя преломления, распределения поля фундаментальной моды и фотография торца световода представлены на Рис.1а) и б). Оценочная отсечка второй моды равнялась 1658 нм, то есть слегка изогнутый (с диаметром 40 см) световод работал в одномодовом режиме.

Полученный световод был протестирован в схеме усилителя, на вход которого подавалось вплоть до 0,6 Вт неприрывного сигнала на длине волны 1557 нм. Накачка осуществлялась многомодовым стабилизированным лазерным диодом с длинной волны 976 нм и мощностью до 25 Вт через объединитель сигнала и накачки $2+1$ в 1 . Выходной торец световода скалывался под углом для подавления генерации в области 1 мкм. Дихроичное зеркало (1550/976) и помещение выходного конца световода в иммерсию использовались для определения мощности усиленного сигнала, рапространяющегося по сердцевине и оценки паразитной генерации ионов иттербия в области 1 мкм. Измеренная зависимость дифференциальной эффективности от длины световода представлена на Рис.1 в). При максимальной накачке (25 Вт) доля мощности в близи 1 мкм составляла не более $1 \%$ от выходной мощности. Таким образом максимальная дифференциальная эффективность была измерена на 5 м световода и составила 19,6\% при максимальной выходной мощности 5 Вт. В схеме лазера максимальная дифференциальная эффективность составила 29\%.

Работа выполнена при поддержке гранта РНФ 17-13-01343.

\section{Литература}

[1] E. Petersen, W. Shi, et al., Appl. Opt., 51, 531, (2012)

[2] O. DE Varona, W. Fittkau, et al., Opt. Express, 25, 2634-2636, (2017)

[3] Z. Zhao, H. Xuan, et al., Opt. Express, 23, 29764, (2015) 